\title{
$-\square$ \\ U.S. GEOLOGICAL SURVEY GROUND-WATER STUDIES IN COLORADO
}

\section{WATER ISSUES}

Water demands in Colorado west of the Continental Divide generally are met by appropriation of surface water, and water demands east of the Continental Divide are met by conjunctive use of ground water and surface water augmented by transmountain diversions. Ground water supplies 18 percent of the total water used in Colorado. Of the total quantity of ground water used, 96 percent is used for irrigation, 2 percent for public supply, 1 percent for rural domestic supplies, and 1 percent for livestock and industrial uses. Public supplies provide ground water to about 320,000 people. The major issues related to ground water in Colorado are:

- Decreasing ground-water supplies,

- Contamination of ground water by hazardous wastes, and

- Effects of land use on ground-water quality.

\section{U.S. GEOLOGICAL SURVEY PROGRAMS}

The U.S. Geological Survey (USGS), established in 1879, is the principal source of scientific and technical expertise in the earth sciences within the Federal government. USGS activities include research and services in the fields of geology, hydrology, and cartography. The mission of the Water Resources Division of the USGS is to develop and disseminate scientific knowledge and understanding of the Nation's water resources. The activities of the Water Resources Division in Colorado are conducted by scientists, technicians, and support staff in offices in Lakewood (two offices), Grand Junction, Durango, Meeker, and Pueblo.

Hydrologic-data stations are maintained at selected locations throughout Colorado and constitute a water-resources-data network for obtaining records on stream discharge and stage, reservoir and lake storage, ground-water levels, well and spring discharge, and the quality of surface and ground water. Waterresources data are stored in the USGS National Water Data Storage and Retrieval System. These data are used by water planners and others involved in making decisions that affect Colorado's water resources.

During 1987, the USGS maintained a network of about 1,570 observation wells in Colorado for monitoring fluctuations in water levels, in cooperation with Federal, State, and local agencies. Water-level measurements from wells are used for monitoring ground-water trends; however, they must be integrated with other observations and ground-water investigations to have the most relevance and usefulness.

The USGS has conducted more than 200 hydrologic investigations in Colorado. During fiscal year 1987, the
USGS entered into agreements with 70 Federal, State, and local agencies involving $\mathbf{4 0}$ hydrologic investigations in Colorado; 22 investigations included studies of ground-water quantity and quality. These investigations will provide information needed to answer hydrologic questions that are specific to the State's principal ground-water issues. Also, some of these investigations will provide information on statewide, multistate, and nationwide hydrologic problems. Three examples of groundwater studies by the USGS that were designed to address specific ground-water issues in Colorado are discussed in the following sections.

\section{GROUND WATER IN THE DENVER BASIN}

Population growth in the Denver area has increased the demand for water. Surface-water supplies are fully appropriated, and ground water is the primary source for new development in the Denver basin, which is underlain by four major bedrock aquifers. Increased pumpage from these aquifers has resulted in a rapid decline in ground-water levels.

Information on ground-water movement, areas of groundwater recharge and discharge, chemical quality of ground water, and the development potential of the aquifer system was needed by State and local officials to effectively manage the resource. From 1975 through 1984, the USGS, in cooperation with the Colorado Department of Natural Resources, Division of Water Resources, Office of the State Engineer, and agencies from six

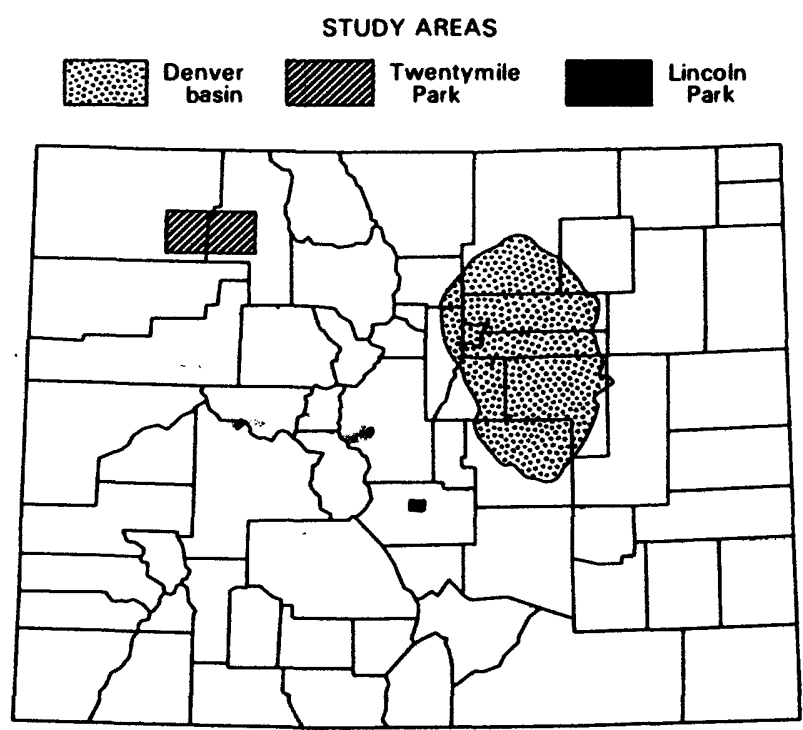


separate counties, studied the ground-water resources of the Denver basin. During the study, geohydrologic data were obtained from about 700 wells, and water-quality data were obtained from about 500 wells. Aquifer tests were made in 80 bedrock wells, and data were compiled for an additional 150 aquifer tests. Maps showing the extent, thickness, structure, sand content, and water quality of the four bedrock aquifers were published. A ground-water flow model of the four principal bedrock aquifers in the Denver basin was constructed. The model was used to define the steady-state water budget and to investigate the water-level response of the aquifers to four alternative ground-water development plans that included various rates of pumping and artificial recharge. The results of this study (Robson, 1987) are used by water managers in the Denver basin to plan for future ground-water development.

\section{GROUND-WATER CONTAMINATION IN LINCOLN PARK}

Water in aquifers that underlie the Lincoln Park area near Canon City contains measurable concentrations of molybdenum, selenium, and uranium that may have been caused by improper disposal of liquid waste from a nearby uranium-ore processing mill. The site has been investigated as part of the Comprehensive Environmental Response, Compensation, and Liability Act of 1980 and has been included in the National Priority List of hazardous-waste sites. The U.S. Environmental Protection Agency determined that additional information was required for their evaluation of the site and requested that the USGS study the affected aquifers in Lincoln Park.

The USGS compiled existing data, and drilled test wells to obtain additional data, on ground-water conditions in Lincoln Park. The data were used to determine which geologic units were contaminated, the extent of contamination, and the movement of the contaminant. The results of this study (Hearne and Litke, 1987) are being used by the U.S. Environmental Protection Agency and the Colorado Department of Health to monitor the effects of remedial action.

\section{EFFECTS OF COAL MINING ON GROUND WATER IN TWENTYMILE PARK}

Mining can adversely affect ground-water resources. Pumpage to dewater mines can lower ground-water levels; seepage of leachate that contains minerals dissolved from mine tailings can pollute ground water. The Colorado Department of Natural Resources, Division of Mined Land Reclamation, U.S. Bureau of Land Management, U.S. Office of Surface Mining Reclamation and Enforcement, and the USGS entered into a cooperative agreement to study the potential effects of coal mining on ground water in the Twentymile Park area of Moffatt and Routt Counties.

The USGS will monitor ground-water levels and quality, conduct aquifer tests, drill test holes to define the ground-water flow system in the area, and develop a computer model of solute transport that is capable of simulating the effects of mining on the ground water. The processes that control the quantity and quality of seepage through reclaimed coal spoils will be evaluated. Regulatory and management agencies will use the results of the study to assess the probable effects of mining on the quantity and quality of ground water.

\section{GROUND-WATER MANAGEMENT}

The principal State agencies responsible for ground-water management in Colorado are the Department of Natural Resources, Division of Water Resources and the Colorado Department of Health. The Division of Water Resources is responsible for the administration of water law in Colorado, and the Department of Health is responsible for coordinating efforts to protect the quality of the State's water resources. Both agencies use ground-water data and the results of ground-water studies provided by the USGS. During 1987-88, the following Federal, State, and local agencies entered into interagency or cooperative cost-sharing agreements with the USGS to conduct ground-water investigations in Colorado:

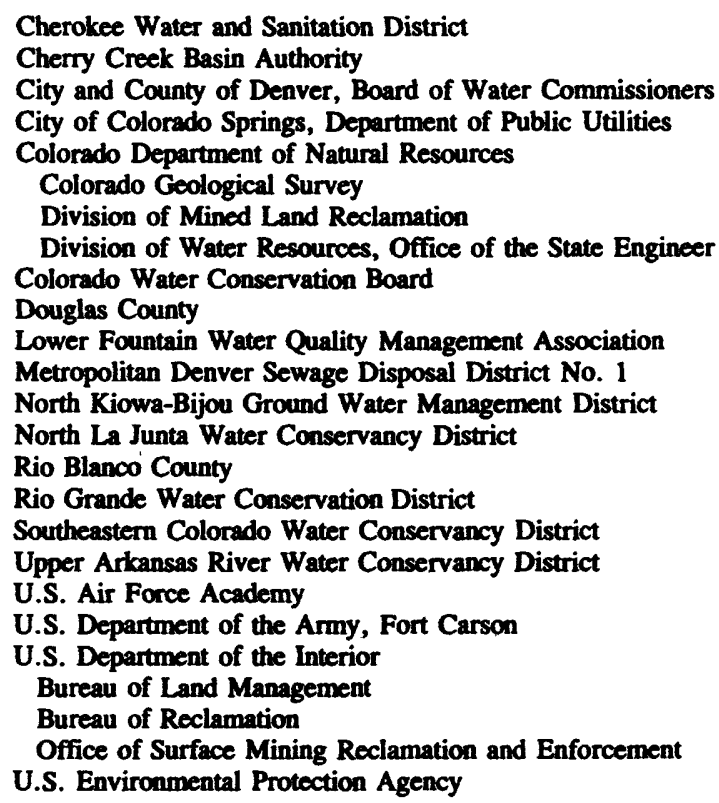

\section{SELECTED REFERENCES}

Hearne, G.A., and Litke, D.W., 1987, Ground-water flow and quality near Canon City, Colorado: U.S. Geological Survey WaterResounces Investigations Report 87-4014, 72 p.

Robson, S.G., 1987, Bodrock aquifers in the Denver basin, Colorado-A quantitative water-resources appraisal: U.S. Geological Survey Professional Paper 1257, 73 p.

Stewart, J.M., compiler, 1987, Summary of water-resources activities of the U.S. Geological Survey in Colorado-fiscal year 1986: U.S. Geological Survey Open-File Report 87-388, 65 p.

U.S. Geological Survey, 1985, National water summary 1984Hydrologic events, selected water-quality trends, and ground-water resources: U.S. Geological Survey Water-Supply Paper 2275, 467 p.

1984, National water summary 1983-Hydrologic events and issues: U.S. Geological Survey Water-Supply Paper 2250, 243 p.

Information on technical reports and data related to ground water in Colorado can be obtained from:

District Chief

U.S. Geological Survey, Water Resources Division

Box 25042, Mail Stop 415

Federal Center

Denver, Colorado 80225

Director

Colorado Water Resources Research Institute

Colorado State University

Fort Collins, Colorado 80523

Open-File Report 88-109

John B. Weeks, 1988 